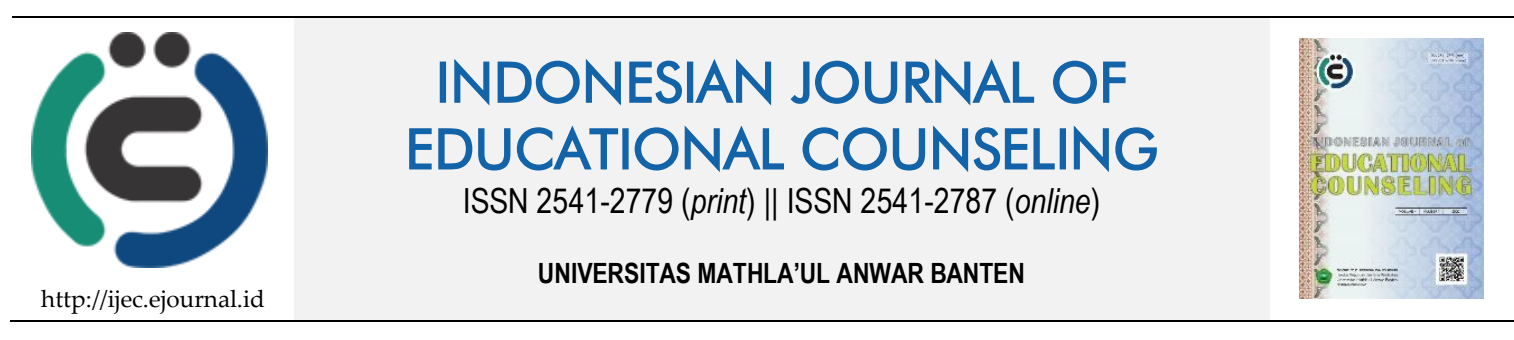

Research Based Article

\title{
Pengaruh Metode Pembelajaran Bahasa Jawa Melalui Bermain Peran terhadap Perilaku Sopan Santun Anak
}

\author{
Atik Masruroh ${ }^{1}$, Nurbiana Dhieni $^{2}$, Karnadi $^{2}$ \\ 1,2 Universitas Negeri Jakarta, Indonesia
}

\begin{tabular}{|c|c|}
\hline Article History & ABSTRACT \\
\hline $\begin{array}{l}\text { Received: } 27.06 .2019 \\
\text { Received in revised form: } \\
\text { 15.08.2019 } \\
\text { Accepted: } 19.12 .2019 \\
\text { Available online: } 28.01 .2020\end{array}$ & $\begin{array}{l}\text { THE EFFECT OF JAVANESE LANGUAGE LEARNING METHODS } \\
\text { THROUGH ROLE PLAYING ON CHILD POLITE BEHAVIOR. The purpose of } \\
\text { this study was to examine how much influence the Javanese language learning } \\
\text { method through playing macro roles and playing micro roles on the behavior } \\
\text { of courtesy in grade } 2 \text { elementary school children in Lamongan Regency. The } \\
\text { behavior of courtesy in this study is based on Javanese culture, focused on three } \\
\text { aspects namely respecting older people, choosing the language level wisely, } \\
\text { and obeying orders. This research was conducted at SDN Made IV and SDN } \\
\text { Sukorejo II. This research was conducted in the odd semester of the 2019/2020 } \\
\text { school year with a total of } 68 \text { research subjects. Data collection techniques using } \\
\text { the method of observation. While the data analysis technique uses t-test, which } \\
\text { has previously been tested for normality and homogeneity. The results showed } \\
\text { that the average value of the experimental class was } 58.24 \text {, while the control } \\
\text { class was } 56.5 \text {. From the results of the study found that the results of a } \\
\text { significant value of } 0.018<0.05 \text {. Then the results are obtained that there are } \\
\text { differences in the average behavior of courtesy between children who are } \\
\text { taught with the Javanese learning method through playing macro roles and } \\
\text { children who are taught with the Javanese learning method through playing } \\
\text { micro roles. Thus, the behavior of the children polite given the Javanese } \\
\text { language learning method through playing macro roles is higher than the } \\
\text { children who were given the Javanese learning method through micro role } \\
\text { playing. }\end{array}$ \\
\hline
\end{tabular}

KEYWORDS: Macro Role Play, Micro Role Play, Polite Behavior.

DOI: $10.30653 / 001.202041 .121$

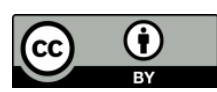

This is an open access article distributed under the terms of the Creative Commons Attribution 4.0 International License, which permits unrestricted use, distribution, and reproduction in any medium, provided the original work is properly cited. ๑ 2020 Atik Masruroh, Nurbiana Dhieni, Karnadi.

\section{PENDAHULUAN}

Memiliki perilaku yang sopan dan santun merupakan suatu kewajiban bagi setiap manusia sebagai makhluk sosial. Oleh karena itu, perilaku sopan santun perlu ditanamkan sejak dini. Karena anak usia dini berada pada usia emas (golden age), di mana pada usia tersebut akan mudah bagi guru dan orang tua untuk mengajarkan dan

${ }^{1}$ Corresponding author's address: Program Studi Bimbingan dan Konseling, FIP Universitas Negeri Jakarta. Jl. Rawamangun Muka, RT.11/RW.14, Rawamangun, Kec. Pulo Gadung, Kota Jakarta Timur, Daerah Khusus Ibukota Jakarta 13220, Indonesia. Email: atikmasruroh_paud17s2@mahasiswa.unj.ac.id 
menanamkan berbagai aspek perkembangan kepada anak. Salah satunya adalah menanamkan perilaku sopan santun kepada anak, yang digunakan sebagai modal dasar untuk berinteraksi dan bergaul dengan lingkungan sosialnya. Seseorang yang memiliki perilaku sopan santun yang baik maka akan mudah diterima di lingkungan sosialnya.

Jika dilihat dari perkembangan moral anak menurut Kohlberg, anak pada usia sebelum 9 tahun masuk dalam tingkat perkembangan moral prakonvensional, di mana moralitas dikendalikan secara eksternal. Anak-anak telah menerima aturan yang berlaku dalam suatu budaya, dan tindakan dinilai berdasarkan konsekuensi yang diterimanya. Perilaku yang menghasilkan hukuman dipandang sebagai perilaku yang buruk dan perilaku yang menghasilkan imbalan dipandang sebagai perilaku yang baik (Santrock, 2011). Jadi, anak sebenarnya sudah dapat menerima aturan yang berlaku dalam suatu kelompok masyarakat, sehingga dalam proses menanamkan nilai sopan santun anak sesuai aturan-aturan yang berlaku dalam masyarakat Jawa juga sudah dapat dilakukan. Asalkan dilakukan melalui cara-cara yang menyenangkan bagi anak.

Atas pertimbangan tersebut, peneliti memilih menggunakan metode bermain peran dalam pembelajaran bahasa Jawa. Karena bermain peran atau yang disebut dengan bermain pura-pura, merupakan salah satu metode pembelajaran yang menarik dan menyenangkan bagi anak. Di mana pada metode bermain peran dapat melibatkan anak secara aktif dalam melakukan kegiatan pembelajaran. Anak dapat memainkan sebuah peran sesuai dengan tokoh yang ada dalam cerita, dan merasakannya secara langsung. Menurut Clawson \& Haskins (2010) metode bermain peran dapat menghidupkan suasana dikelas, di mana dapat meningkatkan perhatian anak-anak serta anak lebih konsentrasi dalam kegiatan. Anak-anak diajak untuk melakukan sebuah simulasi secara langsung yang melibatkan adanya percakapan. Percakapan tersebut dapat membuat anak untuk berpikir lebih aktif. Selain itu bermain peran memperkuat kemampuan anak untuk berempati, mengalami, dan memahami realitas yang dirasakan orang lain. Serta bermain peran juga menghasilkan tingkat pemahaman dan keterampilan anak-anak.

Berdasarkan fakta di lapangan, dalam mata pelajaran bahasa Jawa lebih mengutamakan penggunaan LKS (Lembar Kerja Siswa) di mana pada awal pembelajaran, anak diberikan penjelasan oleh guru sesuai tema hari itu, kemudian dilanjutkan dengan anak memulai mengerjakan LKS sesuai perintah. Hal tersebut membuat anak menjadi pasif dan kurang berperan aktif dalam kegiatan, serta hal tersebut membosankan. Dengan tidak dilibatkannya anak secara aktif, maka apa yang dijelaskan kepada anak mengenai nilai-nilai dalam budaya Jawa dan materi lainnya akan mudah dilupakan oleh anak, karena menjadi tidak bermakna.

Nilai-nilai yang terkandung dalam budaya Jawa yang diajarkan melalui mata pelajaran bahasa Jawa perlu ditanamkan kepada anak sejak dini dengan cara-cara yang menyenangkan. Maka dari itu peneliti menerapkan metode bermain peran. Adapun alasan menggunakan metode bermain peran karena metode ini sangat menyenangkan dan membuat setiap anak menjadi aktif. Penelitian yang dilakukan oleh Vizeshfar, Dehghanrad, Magharei, \& Sobhani (2016) menyatakan bahwa bermain peran adalah metode yang efektif dan menarik dalam pendidikan dan pengajaran, serta dapat meningkatkan moral, kerja kelompok dan mengarah pada pembelajaran secara bersamasama.

Bermain peran atau yang disebut dengan bermain pura-pura, merupakan salah satu metode pembelajaran yang menarik dan menyenangkan bagi anak. Di mana pada metode 
bermain peran dapat melibatkan anak secara aktif dalam melakukan kegiatan dan imajinasi anak dapat berkembang. Anak dapat memainkan sebuah peran sesuai dengan tokoh yang ada dalam cerita. Anak dapat merasakan secara langsung menjadi tokoh yang diperankan dan praktik langsung menggunakan bahasa Jawa. Dengan penggunaan bahasa Jawa secara langsung (praktik langsung) akan memberi kesan atau makna dalam diri anak, sehingga anak akan lebih mudah mengingatnya.

Menurut Myers (2010) peran merupakan serangkaian norma yang mendefinisikan bagaimana seseorang dalam suatu posisi tertentu harus berperilaku. Kata peran (role) merujuk pada aksi yang diharapkan dari anak-anak yang berada pada posisi tertentu dalam suatu cerita yang dimainkan. Bermain peran juga dapat digunakan anak sebagai sarana untuk; 1) mengeksplorasi perasaan, 2) menghasilkan wawasan ke dalam sikap, nilai, dan presepsi, 3) mengembangkan keterampilan dan sikap pemecahan masalah, dan 4) mengeksplorasi materi pelajaran dengan bebagai cara. Jadi, bermain peran memiliki banyak manfaatnya bagi perkembangan anak seperti yang telah diungkapkan dalam teori tersebut di atas.

Bermain peran atau disebut bermain pura-pura menurut Morrison (2012) memungkinkan anak-anak untuk berpartisipasi seolah-olah mengalami sendiri aktivitas di dalam cerita yang diperankan. Biasanya terkait dengan kehidupan keluarga, masyarakat, dan warisan budaya. Permainan drama dibedakan menjadi dua yaitu, sosiodrama dan fantasi. Sosiodrama biasanya melibatkan aktivitas dan peristiwa nyata sehari-hari, sedangkan fantasi melibatkan dongeng dan permainan seperti superhero. Permainan pura-pura atau bermain peran memberikan kesempatan bagi anak untuk mengungkapkan diri, mengambil peran yang berbeda, serta berinteraksi dengan orang lain.

Seefeldt, Castle, \& Falconer (2010) mendefinisikan bahwa bermain peran adalah teknik yang dapat digunakan untuk membantu anak-anak mengambil pandangan orang lain. Sebagai permainan peran anak-anak, mereka memiliki kesempatan untuk mendapatkan wawasan tentang perasaan orang lain, memikirkan alternatif tindakan, dan mengeksplorasi konsekuensi dari tindakan mereka.

Myers (2010) menyatakan bahwa permainan peran ini memperlihatkan bagaimana sesuatu tindakan buatan (tidak nyata) dapat secara signifikan memberikan pengaruh pada suatu keadaan yang nyata. Misalkan dalam suatu cerita yang dimainkan pada cerita mengenai guru, tentara, pelaku bisnis, seseorang dapat melakukan peran tersebut sehingga dapat membentuk sikap seseorang. Dari pengertian tersebut dapat dipahami bahwa, kegiatan bermain peran ini dapat memberikan pengaruh bagi perubahan suatu keadaan yang nyata.

Adapun tahapan-tahapan dalam bermain peran pada anak usia dini menurut Monorom dan Pollock (2006) dilakukan dengan:

1) tahap penjelasan, guru memberikan penjelasan tentang peran yang harus diperankan;

2) tahap interaksi, pemain berinteraksi dengan media atau lawan mainnya;

3) tahap forum, guru memonitor pelaksanaan peran yang dilakukan peserta didik; dan

4) tahap tanya jawab, antara guru dengan anak tentang peran-peran yang telah dilaksanakan (Sitorus, 2012).

Beberapa tahapan bermain peran di atas dapat dimodifikasi sesuai dengan tujuan penelitian. Pada dasarnya pelaksanaan metode bermain peran haruslah sangat 
diperhatikan dalam pemilihan tema dan peran serta alur dalam cerita yang akan dimainkan oleh anak. Bermain peran pada anak usia dini haruslah mengandung alur cerita yang mendidik bagi anak, karena peran yang dimainkan anak akan memberikan pembelajaran bagi anak. Menurut Vygotsky bermain peran disebut juga dengan bermain simbolis, pura-pura, make believe, fantasi, imajinasi, atau main drama. Bermain peran terdapat dua jenisnya yaitu bermain peran makro dan bermain peran mikro (Mutiah, 2010). Berikut perbedaannya:

Tabel 1. Perbedaan Bermain Peran Makro dan Mikro

\begin{tabular}{ll}
\hline Bermain Peran Makro & Bermain Peran Mikro \\
\hline Menurut Vygotski, bermain peran makro & Menurut Vygotski, bermain peran \\
adalah anak bermain peran sesungguhnya & mikro adalah, anak memegang atau \\
dan menjadi seseorang atau sesuatu. Saat & menggerak-gerakkan benda-benda \\
anak memiliki pengalaman sehari-hari & berukuran kecil untuk menyusun \\
dengan bermain peran makro (tema sekitar & adegan. Saat anak bermain peran \\
kehidupan nyata), mereka belajar banyak & mikro, mereka belajar untuk \\
keterampilan pra-akademis seperti & menghubungkan dan mengambil \\
mendengarkan, tetap dalam tugas, & sudut pandang dari orang lain. \\
menyelesaikan masalah, dan bermain kerja & \\
sama dengan orang lain.
\end{tabular}

Seperti hasil eksperimen dalam metode bermain peran yang dilakukan oleh Philip Zimbardo dalam buku Myers (2010) di mana dalam eksperimennya melibatkan mahasiswanya dengan cerita mengenai keadaan dalam penjara dengan peran seperti narapidana, penjaga, dan sebagainya, ternyata jika peran tersebut dilakukan selama beberapa kali dapat mempengaruhi perilaku sebagaimana peran yang dimainkan. Hal tersebut terlihat ketika rencana permainan peran dilakuan dalam waktu 2 minggu, namun harus terhenti setelah berjalan selama 6 hari. Hal tersebut dilakukan karena adanya perubahan perilaku dari pemain, di mana terjadinya kebingunan antara realitas dan ilusi, antara permainan peran dan identitas diri. Berdasarkan hal tersebut maka dapat diambil kesimpulan, bahwa ketika seseorang melakukan permainan peran, dan peran tersebut dilakukan selama beberapa waktu maka akan memberikan dampak bagi perubahan perilaku seseorang.

Sebelum membahas mengenai perilaku sopan santun, perlu kita pahami terlebih dahulu mengenai perilaku yang merupakan tanggapan atau reaksi seseorang terhadap rangsangan yang didapatkan. Albarracín, Blair T. Johnson, \& Mark P. Zanna (2005) menyatakan bahwa perilaku yang dimiliki seseorang yang dipengaruhi oleh adat, sikap, emosi, nilai, etika, kekuasaan, persuasi atau komunikasi yang digunakan untuk memberikan pengaruh terhadap orang lain. Menurut Myers (2010) menyatakan bahwa perilaku dalam suatu budaya merupakan gagasan, sikap, dan tradisi yang dibentuk dalam kelompok budaya tersebut, kemudian dibagi dalam setiap anggota kelompok tersebut, serta disebarkannya dari satu generasi ke generasi berikutnya di dalam kelompok. Berdasarkan pendapat tersebut dapat dipahami bahwa, perilaku seseorang dipengaruhi oleh berbagai faktor terkait. Perilaku dalam suatu budaya akan disebarkan kepada setiap anggota dalam kelompoknya.

Perilaku seseorang haruslah sesuai dengan norma-norma yang berlaku dalam masyarakat agar tidak bertentangan. Norma adalah aturan atau ketentuan yang mengikat dalam suatu kelompok masyarakat yang digunakan sebagai sebuah panduan berperilaku 
dalam kehidupan. Norma menurut Myers (2010) adalah standar perilaku yang diterima dan diharapkan. Norma menentukan perilaku yang tepat atau yang sesuai pada suatu kelompok masyarakat. Dalam makna yang lain disebutkan bahwa, norma juga menggambarkan apa yang kebanyakan orang lakukan, atau sesuatu yang sifatnya normal yaitu yang biasa dilakukan dalam suatu kelompok masyarakat. Jadi, norma adalah ketentuan yang mengikat pada seseorang dalam berperilaku pada suatu kelompok masyarakat tertentu.

Ernawati (2004) menyatakan bahwa sopan santun adalah tata cara pergaulan antara manusia yang meliputi aturan dan tata tertib dalam tindakan yang ditetapkan dan disepakati bersama oleh suatu kelompok masyarakat. Selanjutnya menurut Marzuki (2009) sopan santun merupakan tata krama dalam kehidupan sehari-hari sebagai cerminan kepribadian dan budi pekerti luhur. Menurut Yusuf (2017) sopan santun lebih merujuk pada perbuatan yang dapat digunakan dalam memperlancar pergaulan dan dapat pula digunakan untuk membantu dalam menunjang serta mencapai tujuan yang diinginkan. Berdasarkan pendapat tersebut dapat dipahami bahwa sopan santun merupakan tata cara atau aturan yang merujuk pada perbuatan dalam pergaulan yang sesuai dengan kesepakatan mengenai aturan dan tata cara untuk mencapai suatu tujuan tertentu.

Sejalan dengan hal tersebut Yulianti et al. (2018) menyatakan bahwa sopan santun adalah suatu aturan atau tata cara yang berkembang secara turun temurun dalam suatu budaya di masyarakat yang bisa bermanfaat dalam pergaulan antar sesama manusia sehingga terjalin suatu hubungan yang akrab, saling pengertian, serta saling menghormati. Selanjutnya sopan santun menurut Santoso (2015) adalah tata cara, adat atau kebiasaan yang berlaku dalam suatu kelompok masyarakat untuk memelihara hubungan baik antara sesama manusia. Sopan santun merupakan aturan perilaku yang ditetapkan dan disepakati bersama oleh suatu masyarakat tertentu sehingga kesantunan sekaligus menjadi persyaratan yang disepakati dalam perilaku sosial. Berdasarkan hal tersebut maka dapat dipahami bahwa, perilaku sopan santun antara satu kelompok masyarakat dengan kelompok masyarakat yang lainnya berbeda. Karena sopan santun adalah aturan yang ditetapkan dan disepakati oleh suatu kelompok masyarakat dan harus ditaati oleh setiap anggotanya.

Menurut Coren (2018) sopan santun ditunjukkan melalui pertimbangan rasa hormat kepada orang yang lebih tua. Aturan-aturan dalam sopan santun dipraktikkan oleh orang-orang untuk menunjukkan perilaku yang baik dan merupakan cerminan dari cara seseorang berbudaya. Berdasarkan hal tersebut dapat dipahami bahwa, sopan santun sangat mengedepankan rasa hormat kepada orang yang lebih tua sebagai cerminan perilaku yang baik.

Terdapat beberapa sopan santun pada prinsipnya menurut Poedjosoedarmo (2017) yaitu; pertama, seseorang harus sumanak (ramah) dan tanggap (responsif). Kedua, seseorang harus bijak dalam memilih bahasa atau tingkat bicara, karena tingkat bahasa atau bicara dapat menyiratkan tempat lawan bicara dalam strata sosial. Seseorang harus tepa slira (perhatian) dan andhap asor (sederhana, rendah hati). Ketiga, seseorang harus bijak dalam memilih topik dan tujuan pembicaraan. Topik yang dipilih harus sesuai dengan situasi, latar dan pemandangan, dan acara pidato. Seseorang harus memperhatikan prinsip empan papan (layak untuk pengaturan dan situasi). Keempat harus nuju prana (cocok dengan hati, cobalah untuk menyenangkan) lawan bicaranya. 
Dari teori tersebut dapat dipahami bahwa sopan santun dalam budaya Jawa, yaitu dapat menjadi orang yang responsif, menggunakan tingkatan bahasa dengan tepat, dapat berbicara sesuai situasi, dan dalam berbicara dapat menjaga perasaan orang lain, agar dapat menjadi orang yang disebut dengan sebutan "ngerti toto kromo" (sopan santun).

Berdasarkan pembahasan di atas, peneliti bermaksud untuk mengkaji seberapa besar pengaruh metode bermain peran terhadap perilaku sopan santun pada anak kelas 2 SD di Kecamatan Lamongan, Kabupaten Lamongan. Hal ini dikarenakan perilaku sopan santun merupakan hal yang harus dimiliki oleh setiap anak, karena anak sebagai mahluk sosial yang harus berinteraksi dengan baik di lingkungan sekitarnya. Peneliti merumuskan masalah yang dibahas dalam penelitian ini adalah "apakah terdapat perbedaan kecerdasan interpersonal anak yang di berikan metode bermain peran makro dengan anak yang diberikan metode bermain peran mikro?".

\section{METODE}

Penelitian ini dirancang menggunakan metode eksperimen, untuk mengetahui sejauh mana pengaruh variabel bebas terhadap valiabel terikat. Variabel terikat adalah perilaku sopan santun $(\mathrm{Y})$ sedangkan variabel bebas yang merupakan variabel perlakuan yaitu metode pembelajaran bahasa Jawa melalui bermain peran $(X)$ yang terdiri dari bermain peran makro $\left(\mathrm{X}_{1}\right)$ dan bermain peran mikro $\left(\mathrm{X}_{2}\right)$. Penelitian ini dilakukan di SDN Made IV dan SDN Sukorejo II. Pelaksanaan penelitian dilaksanakan pada semester ganjil tahun ajaran 2019/2020. Penelitian ini disesuaikan dengan jadwal di sekolah tersebut. Populasi dalam penelitian ini adalah seluruh anak kelas 2 SD di kecamatan Lamongan, Kabupaten Lamongan. Adapun populasi dalam penelitan ini adalah seluruh anak kelas 2 SD sebanyak 36 SD, dengan total jumlah anak sebanyak 1.580 yang berada di Kecamatan Lamongan, Kabupaten Lamongan. Kemudian peneliti melakukan random dalam pemilihan sekolah, maka terpilih SDN Made IV dan SDN Sukorejo II. Terdapat sebanyak 50 anak pada SDN Made IV dan sebanyak 50 anak pada SDN Sukorejo II.

Tabel 2. Kisi-kisi Instrumen Perilaku Sopan Santun

\begin{tabular}{lllll}
\hline No. & Aspek & Indikator & $\begin{array}{l}\text { Nomor } \\
\text { Butir }\end{array}$ & $\begin{array}{l}\text { Jumlah } \\
\text { Butir }\end{array}$ \\
\hline 1. & $\begin{array}{l}\text { Menghormati } \\
\text { orang yang } \\
\text { lebih tua }\end{array}$ & $\begin{array}{l}\text { Anak dapat menghormati guru di } \\
\text { sekolah }\end{array}$ & $1-10$ & 10 \\
\cline { 3 - 5 } & $\begin{array}{l}\text { Anak dapat menggunakan kata ganti } \\
\text { dengan tepat }\end{array}$ & 11 & 1 \\
\hline 2. & $\begin{array}{l}\text { Bijak } \\
\text { memilih } \\
\text { tingkatan } \\
\text { bahasa }\end{array}$ & $\begin{array}{l}\text { Anak dapat menggunakan bahasa } \\
\text { Jawa Krama kepada guru }\end{array}$ & $\begin{array}{l}12,13, \\
14\end{array}$ & 3 \\
\cline { 3 - 5 } 3. & $\begin{array}{l}\text { Anak dapat menggunakan bahasa } \\
\text { Jatuh pada } \\
\text { perintah }\end{array}$ & Anak tidak membantah & 15 & 1 \\
\cline { 3 - 5 } & $\begin{array}{l}\text { Anak dapat melaksanakan perintah } \\
\text { dari guru }\end{array}$ & 18 & 1 \\
\hline
\end{tabular}

Analisis data dalam penelitian ini terdiri atas analisis deksriptif dan analisis inferensial. Analisis deskriptif berupa penyajian data dengan daftar distribusi frekuensi 
dan histogram selanjutnya mencari mean, median, modus, simpangan baku, nilai maksimum, dan nilai minimum. Sedangkan analisis Inferensial yang digunakan adalah dengan menguji hipotesis menggunakan uji t-test. Uji t-test digunakan untuk mengetahui ada tidaknya perbedaan yang signifikan antara kelompok eksperimen dan kelompok kontrol. Sebelum pengujian hipotesis menggunakan uji t-test terlebih dahulu dilakukan uji persyaratan analisis yang meliputi uji Normalitas, dan Homogenitas. Uji kenormalan data digunakan uji Liliefors, sedangkan uji homogenitas digunakan uji Barlett.

\section{HASIL DAN PEMBAHASAN}

Instrumen yang telah diuji validitas dan reliabilitasnya akan digunakan untuk mengukur perilaku sopan santun anak. Skor total hasil pengukuran baik pada kelompok eksperimen dan kelompok kontrol, kemudian dihitung untuk melihat ukuran pemusatan dan penyebaran datanya.

Tabel 3. Rekapitulasi Data

\begin{tabular}{llllllll}
\hline Variabel & Rerata & Median & Modus & Stdev & Varians & $\begin{array}{l}\text { Skor } \\
\text { Max }\end{array}$ & $\begin{array}{l}\text { Skok } \\
\text { Min }\end{array}$ \\
\hline $\begin{array}{l}\text { Kelompok } \\
\text { Eksperimen }\end{array}$ & 58.24 & 58 & 58 & 3.29 & 10.82 & 64 & 53 \\
\hline Kelompok Kontrol & 56.5 & 57 & 58 & 2.57 & 6.72 & 62 & 52 \\
\hline
\end{tabular}

\section{Uji Normalitas}

Uji normalitas data dilakukan untuk mengetahui apakah sampel berasal dari populasi yang berdistribusi normal. Uji normalitas pada penelitian ini menggunakan uji Liliefors. Adapun syarat dari uji normalitas dengan kriteria $\mathrm{H}_{0}$ diterima jika Lhitung $<$ Ltabel maka data berasal dari distribusi normal dan $\mathrm{H}_{0}$ ditolak jika Lhitung $>$ Ltabel maka data berasal dari distribusi tidak normal. Berikut perumusan hipotesisnya :

$\mathrm{H}_{0}$ : sampel berasal dari populasi berdsitribusi normal

$\mathrm{H}_{1}$ : sampel berasal dari populasi berdistribusi tidak normal

Berdasarkan hasil perhitungan uji normalitas pada semua data kelompok penelitian diketahui bahwa Lhitung untuk semua kelompok lebih kecil dari dari pada Ltabel, ini berarti menunjukkan bahwa semua kelompok penelitian berdistribusi normal. Hasil perhitungan uji coba normalitas dengan uji Liliefors secara keseluruhan dapat dilihat pada Tabel 4.

Tabel 4. Rangkuman Hasil Uji Homogenitas

\begin{tabular}{lllll}
\hline Kelompok & $\mathrm{N}$ & Lhitung & Ltabel & Kesimpulan \\
\hline $\mathrm{A} 1$ & 34 & 0.12 & 0.1497 & Normal \\
\hline $\mathrm{A} 2$ & 34 & 0.09 & 0.1497 & Normal \\
\hline
\end{tabular}

\section{Uji Homogenitas}

Uji homogenitas bertujuan untuk melihat apakah sampel yang berdistribusi normal berasal dari populasi yang variansinya homogen. Untuk menguji kesamaan varians antar kelompok berdasarkan data skor perilaku sopan santun anak, maka masing-masing 
kelompok perlakuan dilakukan uji Barlett pada taraf signifikan $\alpha=0,05 ; \mathrm{dk}=\mathrm{k}-1$. Kriteria pengujian ini apabila $X^{2}$ hitung $<X^{2}$ tabel, maka data tersebut memiliki varians yang homogeny. Hasil perhitungan uji coba Homogenitas dengan uji Bartlett secara keseluruhan dapat dilihat pada Tabel 5 .

Tabel 5. Rangkuman Hasil Uji Homogenitas

\begin{tabular}{llll}
\hline Kelompok & X2hitung & X2tabel & Kesimpulan \\
\hline A1 dan A2 & 0.76 & 3,841 & Homogen
\end{tabular}

Berdasarkan Tabel 5 dapat dilihat bahwa hasil perhitungan uji homogenitas dari ketiga kelompok data diperoleh $\mathrm{X}^{2}$ hitung lebih kecil dari $\mathrm{X}^{2}$ tabel berdasarkan taraf $\alpha=0,05$. Maka dapat disimpulkan keempat kelompok data mempunyai varians yang sama besar, maka kelompok data tersebut bersifat homogen.

Hasil pengujian normalitas dan homogenitas dari data tersebut menunjukkan bahwa kelompok-kelompok data pada penelitian ini berasal dari populasi yang berdistribusi normal dan memiliki varians data yang homogen. Berdasarkan hal tersebut maka persyaratan untuk melakukan pengujian hipotesis dengan uji t dapat dilakukan.

\section{Pengujian Hipotesis}

Uji t digunakan untuk mengetahui ada tidaknya perbedaan yang signifikan antara kelompok eksperimen dengan kelompok kontrol. Adapun dasar pengambilan keputusan pada uji t-test adalah :

Jika nilai signifikansi $(2$-tailed $)<0.05$, maka terdapat perbedaan yang signifikan antara perilaku sopan santun anak yang menggunakan metode pembelajaran bahasa Jawa melalui bermain peran makro dan mikro.

Jika nilai signifikansi (2-tailed) $>0.05$, maka tidak terdapat perbedaan yang signifikan antara perilaku sopan santun anak yang menggunakan metode pembelajaran bahasa Jawa melalui bermain peran makro dan mikro.

Berdasarkan rangkuman uji hipotesis bahwa hasil nilai signifikansi (2-tailed) diperoleh sebesar $0.018<\alpha=0,05$. Maka terbukti bahwa terdapat perbedaan perilaku sopan santun antara anak yang di ajar dengan metode pembelajaran bahasa Jawa melalui bermain peran makro dan anak yang diajar dengan metode pembelajaran bahasa Jawa melalui bermain peran mikro. Hasil penelitian telah menunjukkan bahwa secara keseluruhan kelompok anak yang di ajar dengan metode pembelajaran bahasa Jawa melalui bermain peran makro lebih tinggi dibandingkan dengan kelompok anak yang diajar dengan metode pembelajaran bahasa Jawa melalui bermain peran mikro. Berdasarkan hal tersebut maka, dapat dinyatakan bahwa metode pembelajaran bahasa Jawa melalui bermain peran makro memiliki keunggulan yang lebih daripada metode pembelajaran bahasa Jawa melalui bermain peran mikro untuk meningkatkan perilaku sopan santun anak.

Berdasarkan perbedaan ini dapat dijelaskan bahwa menggunakan metode pembelajaran bahasa Jawa melalui bermain peran makro untuk meningkatkan perilaku sopan santun pada pada anak-anak lebih efektif dibandingkan dengan metode bermain peran mikro. Hal tersebut dikarenakan, melalui bermain peran makro memungkinkan anak-anak berpartisipasi seolah-olah mengalami sendiri aktivitas di dalam cerita yang diperankan. Biasanya terkait dengan kehidupan keluarga, masyarakat, dan warisan budaya (Morrison, 2012). 
Dalam bermain peran makro anak dapat mengeksplore banyak sekali gerakangerakan tubuh secara maksimal dan benar-benar merasakan menjadi apa yang anak perankan. Sedangkan, dalam bermain peran mikro anak sebagai dalang hanya mampu menjalankan dan menggerak-gerakkan benda yang dimainkannya, sehingga anak tidak mempraktikkannya secara langsung terhadap dirinya.

Setiap metode pembelajaran bermain peran dibutuhkan peran anak secara aktif dalam melakukan kegiatan, serta imajinasi anak dapat berkembang. Anak dapat memainkan sebuah peran sesuai dengan tokoh yang ada dalam cerita. Anak dapat merasakan secara langsung menjadi tokoh yang diperankan dan praktik langsung menggunakan bahasa Jawa. Dengan penggunaan bahasa Jawa secara langsung (praktik langsung) akan memberi kesan atau makna dalam diri anak, sehingga anak akan lebih mudah mengingatnya dan nilai-nilai yang terkandung dalam budaya Jawa dapat tertanam dalam diri setiap anak.

Menurut Clawson \& Haskins (2010) metode bermain peran dapat menghidupkan suasana dikelas, di mana dapat meningkatkan perhatian anak-anak serta anak lebih konsentrasi dalam kegiatan. Anak-anak diajak untuk melakukan sebuah simulasi secara langsung yang melibatkan adanya percakapan. Percakapan tersebut dapat membuat anak untuk berpikir lebih aktif. Permainan peran menyajikan suatu cerita yang bersifat abstrak menjadi lebih hidup. Selain itu bermain peran memperkuat kemampuan anak untuk berempati, mengalami, dan memahami realitas yang dirasakan orang lain. Serta bermain peran juga menghasilkan tingkat pemahaman dan keterampilan anak-anak.

Selama proses penelitian terlihat perkembangan sopan santun anak-anak. Seperti contohnya anak-anak bersalaman dengan mengucapkan salam saat bertemu guru, yang biasanya hanya bersalaman tanpa mengucapkan salam. Contoh lainnya yang Nampak dalam penelitian, di mana pada saat melewati guru/orang yang lebih tua ataupun temannya langsung lewat saja, setelah dilakukan perlakuan anak dapat mengucapkan "nuwun sewu/amit". Perilaku-perilaku sopan santun tersebut mulai dibiasakan anak-anak dalam kehidupan sehari-harinya terutama di sekolah. Memang menekankan hal tersebut ke anak-anak sangatlah penting. Guru harus selalu mengingatkan anak-anak dalam bagaimana seharusnya berperilaku yang sopan dan santun.

Berdasarkan pembahasan hasil penelitian tersebut, maka dapat direkomendasikan bahwa metode pembelajaran bahasa Jawa melalui bermain peran makro sebagai salah satu metode pembelajaran bahasa Jawa yang dapat digunakan untuk menanamkan perilaku sopan santun pada anak. Hal tersebut dikarenakan, pada metode pembelajaran bahasa Jawa melalui bermain peran makro anak dituntut menjadi aktif dalam kegiatan. Selain itu anak juga memerankan peran lain dengan menjalankan berbagai peran yang sesuai dengan cerita yang sudah ditentukan. Di mana pada cerita tersebut terdapat praktik-praktik perilaku sopan santun. Melalui peran yang dimainkan anak tersebut, maka akan menjadi bermakna bagi anak serta anak dapat menerapkannya dalam kehidupannya sehari-hari. Tentunya hal tersebut juga perlu didukung oleh lingkungan anak, seperti guru dan orang tua sebagai penguatan.

\section{SIMPULAN}

Berdasarkan penelitian yang dilakukan, maka dapat disimpulkan bahwa metode pembelajaran bahasa Jawa melalui bermain peran makro dan bermain peran mikro sama- 
sama memiliki pengaruh terhadap perilaku sopan santun anak. Namun, perilaku sopan santun anak yang diberikan metode pembelajaran bahasa Jawa melalui bermain peran makro lebih tinggi dibandingkan anak yang diberikan metode pembelajaran bahasa Jawa melalui bermain peran mikro. Berdasarkan temuan tersebut maka, dapat direkomendasikan bahwa metode pembelajaran bahasa Jawa melalui bermain peran makro lebih tepat digunakan dalam menanamkan perilaku sopan santun pada anak.

\section{REFERENSI}

Albarracín, D., Johnson, B. T., \& Zanna, M. P. (2005). The handbook of attitudes. Abingdon: Routledge. Retrieved from https://www.routledgehandbooks.com/pdf/doi/10.4324/9781410612823.ch3

Clawson, J. G. S., \& Haskins, M. E. (2010). Role-playing. In Teaching Management (pp. 141153). https://doi.org/10.1017/CBO9780511617850.010

Coren. (2018). Etiquette. Salem Press Encyclopedia. Pasadena, CA: Salim Press.

Ernawati, U. (2004). Pedoman lengkap kesekretarisan untuk sekretaris dan calon sekretaris. Yogyakarta: Graha Ilmu.

Marzuki. (2009). Prinsip dasar akhlak mulia pengantar studi konsep-konsep dasar etika dalam Islam. Yogyakarta: Debut Wahana Press.

Morrison, G. S. (2012). Dasar-dasar pendidikan anak usia dini. Jakarta: Indeks.

Mutiah, D. (2010). Psikologi Bermain Anak Usia Dini. Jakarta: Kencana.

Myers, D. D. (2010). Social psychology (10th ed.). New York: McGraw-Hill.

Poedjosoedarmo, S. (2017). language propriety in javanese. Journal of Language and Literature, 17(1), 1-9.

Santoso, T. (2015). Kajian linguistik kontrastif (Tingkatan Bahasa dalam Bahasa Jepang dan Unda-usuh Bahasa Jawa). Yogyakarta: Morfalingua.

Santrock, J. W. (2011). Masa perkembangan anak. Jakarta: Salemba Humanika.

Seefeldt, C., Castle, S., \& Falconer, R. C. (2010). Social studies for the preschool/primary child (8th ed.). USA: Pearson.

Sitorus, M. (2012). Peningkatan Kompetensi Sosial Anak Usia Dini Dengan Metode Bermain Peran (Studi Kasus di Raudhatul Athfal Muhajirin-Medan). Jurnal Pendidikan dan Kebudayaan, 18(1), 98-106. https://doi.org/10.24832/jpnk.v18i1.72

Vizeshfar, F., Dehghanrad, F., Magharei, M., \& Sobhani, S. M. J. (2016). Effects of applying role playing approach on nursing students' education. International Journal of Humanities and Cultural Studies, 1772-1781.

Yulianti, I., Isnani, A., Zakkiyyah, A. L., \& Hakim, J. (2018). Penerapan bahasa jawa krama untuk membentuk karakter sopan santun di sekolah dasar. In Makalah. Prosiding Seminar Nasional di Universitas Muria Kudus. Kudus (Vol. 11, pp. 160-165).

Yusuf, I. M. (2017). Etika vs etiket (Suatu telaah tentang tuntutan dan tuntunan dalam penyelenggaraan pelayanan publik). Moderat, 3(2), 60-78. 